\title{
Cluster Front Line Demonstrations of Green Gram under National Food Security Mission in Sriganganagar District: An Evaluation of Production and Productivity of Green Gram
}

\author{
Rupesh Kumar Meena ${ }^{1}$, Bhupender Singh ${ }^{2}$, Kuladip Prakash Shinde $^{3}$ \\ and Ravi Kumar Meena ${ }^{4}$ \\ Krishi Vigyan Kendra, Sriganganagar, S.K. Rajasthan Agri. University, \\ Bikaner (Rajasthan), India \\ *Corresponding author
}

Keywords

FLD, Farmer Practices, Green Gram, SML 668, IPM 02-3 and Yield.

Article Info

Accepted:

18 May 2020

Available Online:

10 June 2020

A B S T R A C T

Front line demonstration of green gram were conducted from 2010-11 to 201718 at the farmer's fields of operational area of Krishi Vigyan Kendra, Sri Ganganagar in Irrigated North Western Plain Zone- 1b of Rajasthan. The findings of seven years front line demonstrations indicated that improved green gram varieties i.e. SML 668 and IPM 02-3 with full package under demonstration had significant impact on seed yield compared to local varieties used by farmer. Further, mean results of the study revealed that average additional yield $(1600 \mathrm{~kg}$ ), yield increase $(23.09 \%)$, net monetary return (Rs. 28226), additional returns (Rs. 7014), effective gain (Rs. 6002) and benefit: cost ratio (4.06) from one hectare were obtained as compared to farmer practices. It may be concluded that adoption of improved production technologies of green gram can reduce the technology gap to a considerable extent thus leading to increased productivity and also found productive, economic viable and also feasible to local conditions as compared to existing farmer practices.

\section{Introduction}

Green gram (Vigna radiata L.) is commonly named as Mung bean. It is the most important Kharif (Rainy) season pulse crop in India. Green gram is one of the thirteen food legumes grown in India and the third most important pulse crop after chickpea and Pigeonpea. Green gram is a protein rich staple food. Because of its better nutritional quality, it is called as "Queen of pulses". It contains about 25 percent protein, which is almost three times that of cereals. It supplies protein requirement of vegetarian population of the country. In addition to being an important source of human food and animal feed, Green gram also plays an important role in sustaining soil fertility by improving soil 
physical properties and fixing atmospheric nitrogen. The green gram production among pulses was 971322 metric tons from the area of 2249619 hectare with productivity of 4.32 q/ha. in Rajasthan in the year 2017-18. Whereas, in Sriganganagar district total production of kharif green gram was 27335 metric tons from the area of 52219 hectare with productivity of $5.23 \mathrm{q} / \mathrm{ha}$.

The FLD is an important tool for transfer of latest package of practices in totality to farmers and the main objective of this programme is to demonstrate newly released crop production and protection technologies and management practices at the farmers field under real farming situation. Through this practice, the newly improved innovative technology having higher production potential under the specific cropping system can be popularized and simultaneously feedback from the farmers may be generated on the demonstrated technology (Singh et al., 2012).

\section{Materials and Methods}

CFLDs on green gram were conducted in cluster mode (group of villages) at farmers' fields in the close supervision of scientists of KVK Sriganganagar. As per the agro climatic zones of Rajasthan Sriganganagar district comes under Irrigated North Western Plain Zone-1b. Green gram varieties i.e. SML 668 and IPM 02-3 which have been released/notified within 10 years were demonstrated at farmers' fields. During Kharif 2010-11 to 2018-19, 305 CFLDs on green gram were conducted by KVK Sriganganagar of Rajasthan in 122 ha area. For individual farmer, 0.4 ha area is allotted under demonstration. Full package of practices of green gram were demonstrated in addition to promote Integrate Nutrient Management (INM), Integrated Pest Management (IPM) to realize better yield. As a critical input, supply of chemical fertilizers is not supported under CFLDs. All the participating farmers were trained on various aspects of green gram production technologies. Field days are organized with active involvement of state line departments to make awareness among farmers. Data on results of CFLDs collected by KVK Sriganganagar from partner farmers where CFLDs were undertaken. Parameters on which data collected were total area demonstrations under CFLDs, yield under farmers practice and CFLDs, weighted mean, enhanced yields, gap minimized in comparison to district and potential yield, net return, benefit cost ratio, net income were calculated to draw meaningful results. The extension gap, technology gap and technology index were worked out (Katare et al., 2011, Samui et. al., 2000) as given below:

Technology gap $=$ Potential yieldDemonstration yield

Extension gap $=$ Demonstration yield- Farmers yield

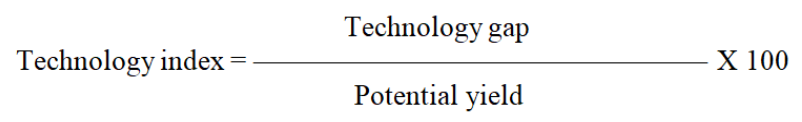

\section{Results and Discussion}

\section{Differentiation in demonstration package and farmer practice in green gram crop}

Results of cluster front line demonstration indicate that major differences were observed between demonstration package and local farmer's practice regarding improved variety , proper seed rate, seed treatment, sowing method, nutrient management and plant protection measures. Table 1 show that under the demonstrated plot recommended improved variety, bio-fertilizers, herbicide and insecticide for plant protection measure were given to the farmers by the KVK and all other package and practices were timely performed by the farmer itself under the 
supervision of KVK scientist. Under farmer practice they generally sow seed of green gram var. K 851 and Ganga 8 at low seed rate without treatment. Similar findings have also been observed by Singh et al., (2012) and Raj et al., (2013).

\section{Performance of FLD programme on production and economics of green gram}

Under NFSM-Pulses, total 305 CFLDs were demonstrated during 2010-11 to 2018-19 to showcase potentials of improved varieties and performance recommended package of practices in agro-climatic zone of Sriganganagar. The results obtained during last seven years are presented in Table 2 revealed that the average yield of green gram under FLD plots varied between $7.25 \mathrm{q} / \mathrm{ha}$ to $10.75 \mathrm{q} / \mathrm{ha}$, whereas, under the farmer practice (Local check), it varied between $5.80 \mathrm{q} / \mathrm{ha}$ to $9.25 \mathrm{q} / \mathrm{ha}$. The FLD plots recorded 16.22 to 28.64 per cent increase in yield over the local check. The average increase in per cent of yield was $21.27 \mathrm{q} / \mathrm{ha}$ was recorded during seven years of study. The results clearly indicate the positive effects of CFLDs over the existing practices toward enhancing the yield of green gram in different clusters of Sriganganagar district. Farmers were motivated by results of improved practices applied in FLDs trial. The higher yield of green gram could be attributed due to adoption of improved variety of green gram. These results were also supported by Baldev Ram et al., (2013).Yield of the front line demonstration, potential yield and district yield of the crop was compared to estimate the yield gaps which were further categorized in to technology index.

\section{Technology gap}

During 2010 to 2013, demonstration of SML668 variety, the technology gap was highest (3.14 q/ha) during 2010 and lowest (0.25 $\mathrm{q} /$ ha) during 2013. Further, demonstration of IPM 02-3 variety during 2015 to 2018, the technology gap was highest $(3.75 \mathrm{q} / \mathrm{ha})$ during 2015 and lowest $(2.5 \mathrm{q} / \mathrm{ha})$ during 2016. The difference in technology gap during different years of demonstration is due to better performance of recommended varieties with different interventions and more feasibility of recommended technologies during the demonstrations and some extent to variation in soil fertility and climate conditions. Hence, a location specific recommendation appears to be necessary to bridge the technology gap. Similar findings were recorded by (Singh et al., 2012 and Patel et al., 2013).

\section{Extension gap}

Evaluation of the findings of study (Table 2) stated that the extension gap ranging between 0.6-2.38 $\mathrm{q} / \mathrm{ha}$ was found between demonstrated technology and local check during 2010 to 2013, demonstration of green gram variety SML-668. The extension gap was highest (2.38 q/ha) during 2012 and lowest (0.6 q/ha) during 2011. Further, demonstration of IPM 02-3 variety during 2015 to 2018, the extension gap was highest ( $2.5 \mathrm{q} / \mathrm{ha})$ during 2016 and lowest (1.30 q/ha) during 2018. To minimize the extension gap it is need to educate the farmers through various means for more adoption of improved high yielding variety and recommended practices to bridge the wide extension gap.

\section{Technology index}

During front line demonstration of green gram variety SML-668, the highest (28.5\%) and lowest $(2.3 \%)$ technology index was recorded during year of 2010 and 2013, respectively. Further, as such fluctuation in technology index (ranging between 22.73 to 34.09 per cent) under demonstration of IPM 02-3 variety during 2015 to 2018. 
Table.1 Details of demonstration package and farmers practices under FLD on Green gram crop in Sriganganagar district of Rajasthan

\begin{tabular}{|c|c|c|}
\hline $\begin{array}{l}\text { Technology } \\
\text { Component }\end{array}$ & Demonstration package & Farmer practice \\
\hline Variety & SML 668 \& IPM 02-3 & K 851, Ganga 8 \& Local seed \\
\hline Seed rate & $16-20 \mathrm{~kg} / \mathrm{ha}$ & $12-15 \mathrm{~kg} / \mathrm{ha}$ \\
\hline Sowing Method & $\begin{array}{l}\text { Line sowing through seed cum ferti } \\
\text { drill }\end{array}$ & Line sowing through seed drill \\
\hline Seed treatment & $\begin{array}{l}\text { Seed treatment with Bavistin } 3 \mathrm{~g} / \mathrm{kg} \\
\text { seed and Rhizobium \& PSB } 3 \\
\text { packets/ha. seed }\end{array}$ & Partial seed treatment \\
\hline Weed management & $\begin{array}{l}\text { Weed management by using herbicide } \\
\text { Imazethapyr } 10 \% \text { SL @ } 40 \mathrm{~g} \text { a.i./ha as a } \\
\text { post emergence }\end{array}$ & $\begin{array}{l}\text { No weed management by } \\
\text { using herbicide or One hand } \\
\text { weeding at } 30 \text { DAS }\end{array}$ \\
\hline $\begin{array}{l}\text { Nutrient } \\
\text { Management }\end{array}$ & $\begin{array}{l}\text { Nitrogen } 20 \mathrm{~kg} / \mathrm{ha} \text { and Phosphorus } 40 \\
\mathrm{~kg} / \mathrm{ha}\end{array}$ & Irrational use of fertilizers \\
\hline Plant Protection & $\begin{array}{l}\text { Pod borer major insect in green gram } \\
\text { to control with Qninolfos } 25 \mathrm{EC} \text { or } \\
\text { Monocrotophos } 36 \mathrm{WSC} 1 \text { liter/ha or } \\
\text { Need based spray of insecticides and } \\
\text { fungicide. } \\
\text { For sucking pest spray of Dimethoate } \\
30 \text { EC @ } 1 \mathrm{~L} / \mathrm{ha} \text {. }\end{array}$ & $\begin{array}{l}\text { Over dose/un-recommended } \\
\text { brands of insecticides and } \\
\text { fungicide }\end{array}$ \\
\hline
\end{tabular}

Table.2 Performance of green gram in improved and farmer practices through front line demonstration at farmer field in Sriganganagar district of Rajasthan

\begin{tabular}{|c|c|c|c|c|c|c|c|c|c|c|}
\hline Year & $\begin{array}{c}\text { FLDs } \\
\text { Variety }\end{array}$ & $\begin{array}{c}\text { Area } \\
\text { (ha.) }\end{array}$ & $\begin{array}{c}\text { No. of } \\
\text { Demons. }\end{array}$ & $\begin{array}{c}\text { Demo. } \\
\text { Yield } \\
\text { (Qt./ha) }\end{array}$ & $\begin{array}{c}\text { Local } \\
\text { practice } \\
\text { Yield } \\
\text { (Qt./ha) }\end{array}$ & $\begin{array}{c}\text { \% } \\
\text { Increase } \\
\text { over local }\end{array}$ & $\begin{array}{c}\text { Potential } \\
\text { Yield } \\
(\mathbf{q} / \mathbf{h a})\end{array}$ & $\begin{array}{c}\text { Technology } \\
\text { gap } \\
(\mathbf{q} / \mathbf{h a})\end{array}$ & $\begin{array}{c}\text { Extension } \\
\text { gap } \\
(\mathbf{q} / \mathbf{h a})\end{array}$ & $\begin{array}{c}\text { Technolog } \\
\mathbf{y} \text { index } \\
(\mathbf{\%})\end{array}$ \\
\hline $\mathbf{2 0 1 0 - 1 1}$ & SML 668 & 12 & 30 & 7.86 & 6.42 & 22.43 & 11 & 3.14 & 1.44 & 28.5 \\
\hline $\mathbf{2 0 1 1 - 1 2}$ & SML 668 & 12 & 30 & 9.3 & 8.7 & 6.90 & 11 & 1.7 & 0.6 & 15.5 \\
\hline $\mathbf{2 0 1 2 - 1 3}$ & SML 668 & 12 & 30 & 10.69 & 8.31 & 28.64 & 11 & 0.31 & 2.38 & 2.8 \\
\hline $\mathbf{2 0 1 3 - 1 4}$ & SML 668 & 12 & 30 & 10.75 & 9.25 & 16.22 & 11 & 0.25 & 1.5 & 2.3 \\
\hline $\mathbf{2 0 1 5 - 1 6}$ & IPM 02-3 & 4 & 10 & 7.25 & 5.8 & 25.00 & 11 & 3.75 & 1.45 & 34.1 \\
\hline $\mathbf{2 0 1 6 - 1 7}$ & IPM 02-3 & 20 & 50 & 8.5 & 6 & 41.67 & 11 & 2.5 & 2.5 & 22.7 \\
\hline $\mathbf{2 0 1 8 - 1 9}$ & IPM 02-3 & 50 & 125 & 7.55 & 6.25 & 20.80 & 11 & 3.45 & 1.30 & 31.4 \\
\hline
\end{tabular}


Table.3 Economic analysis of FLDs in green gram in Sriganganagar district of Rajasthan

\begin{tabular}{|c|c|c|c|c|c|c|c|c|c|c|c|}
\hline \multirow[t]{2}{*}{$\begin{array}{l}\text { Season and } \\
\text { year }\end{array}$} & \multicolumn{2}{|c|}{$\begin{array}{l}\text { Average Cost of } \\
\text { cultivation (Rs./ha) }\end{array}$} & \multirow{2}{*}{$\begin{array}{l}\text { Additional } \\
\text { cost in } \\
\text { demo. } \\
\text { (Rs/ha.) }\end{array}$} & \multicolumn{2}{|c|}{$\begin{array}{c}\text { Average Gross Return } \\
\text { (Rs./ha) }\end{array}$} & \multirow{2}{*}{$\begin{array}{l}\text { Additional } \\
\text { return in } \\
\text { demo. } \\
\text { (Rs./ha.) }\end{array}$} & \multicolumn{2}{|c|}{$\begin{array}{l}\text { Average Net } \\
\text { Return } \\
\text { (Rs./ha) }\end{array}$} & \multirow[t]{2}{*}{$\begin{array}{c}\text { Effective } \\
\text { gain } \\
\text { (Rs./ha) }\end{array}$} & \multicolumn{2}{|c|}{ Benefit-Cost Ratio } \\
\hline & Demo. & $\begin{array}{l}\text { Local } \\
\text { Check }\end{array}$ & & Demo. & $\begin{array}{l}\text { Local } \\
\text { Check }\end{array}$ & & Demo & $\begin{array}{l}\text { Local } \\
\text { Check }\end{array}$ & & Demo. & $\begin{array}{l}\text { Local } \\
\text { Check }\end{array}$ \\
\hline 2010-11 & 8250 & 7760 & 490 & 53256 & 44063 & 9193 & 45006 & 37246 & 7760 & 6.46 & 5.68 \\
\hline 2011-12 & 8250 & 7760 & 490 & 27579 & 23934 & 3645 & 19329 & 16174 & 3155 & 3.34 & 3.08 \\
\hline 2012-13 & 8750 & 8000 & 750 & 29085 & 24570 & 4515 & 20335 & 16570 & 3765 & 3.32 & 3.07 \\
\hline 2013-14 & 8925 & 8150 & 775 & 41625 & 36000 & 5625 & 32700 & 27850 & 4850 & 4.66 & 4.42 \\
\hline 2015-16 & 9375 & 8600 & 775 & 33713 & 26970 & 6743 & 24338 & 18370 & 5968 & 3.60 & 3.14 \\
\hline 2016-17 & 9500 & 8700 & 800 & 44412 & 31350 & 13062 & 34912 & 22650 & 12262 & 4.67 & 3.60 \\
\hline 2018-19 & 15255 & 13200 & 2055 & 36216 & 29904 & 6312 & 20960 & 16704 & 4256 & 2.37 & 2.27 \\
\hline Total/Avg. & 9758 & 8881 & 876 & 37984 & 30970 & 7014 & 28226 & 22223 & 6002 & 4.06 & 3.61 \\
\hline
\end{tabular}

This may be attributed due to dissimilarity in soil fertility status, variation in climate, insect-pests and disease attack. These findings are in conformity of the results of study carried out by Meena and Singh (2017) and Dayanand et al., (2012).

\section{Economic analysis}

Economics of improved production practices under front line demonstration were estimated on the basis of prevailing market rates recorded higher average net monetary return (Rs. 28226 /ha.), additional returns (Rs. 7014/ha.), effective gain (Rs. 6002/ha.) and benefit: cost ratio (4.06) as compared to farmer practices under average of last seven years of demonstrations. The higher additional returns and effective gain obtained under demonstration could be due to improved technology and non-monetary factors, timely operations of crop cultivation and scientific monitoring.

The results suggest that improvement in productivity and of economic viability of green gram were obtained by adoption of improved practice under specific agroecological situation. Similarly result has earlier being reported on green gram by Meena and Singh (2017) and on mustard by Meena et al., (2018). This may be attributed due to dissimilarity in soil fertility status, variation in climate, insect-pests and disease attack. These findings are in conformity of the results of study carried out by Meena and Singh (2017) and Dayanand et al., (2012).

\section{Economic analysis}

Economics of improved production practices under front line demonstration were estimated on the basis of prevailing market rates recorded higher average net monetary return (Rs. 28226 /ha.), additional returns (Rs. 7014/ha.), effective gain (Rs. 6002/ha.) and benefit: cost ratio (4.06) as compared to farmer practices under average of last seven years of demonstrations.

The higher additional returns and effective gain obtained under demonstration could be due to improved technology and nonmonetary factors, timely operations of crop cultivation and scientific monitoring. The results suggest that improvement in productivity and of economic viability of green gram were obtained by adoption of improved practice under specific agroecological situation. Similarly result has earlier being reported on green gram by Meena and Singh (2017) and on mustard by Meena et al., (2018). The front line demonstration conducted on green gram at the 
farmer's field revealed that adoption of improved production technologies of green gram found productive, economic viable and also feasible to local conditions as compared to existing farmer practices.

For wide dissemination of improved technologies Horizontal spread of improved technologies may be achieved by the successful implementation of frontline demonstrations and various extensions activities like training programme, field day, exposure visit organized in CFLDs programmes in the farmer's fields. For wide dissemination of improved technologies recommended by SAUs and other research institute, more number of front line demonstrations should be conducted. Adoption of improved technology of green gram cultivation can reduce the technology gap to a considerable extent thus leading to increased productivity of green gram in the Sriganganagar district of Rajasthan.

\section{References}

Anonymous. 2017-18. $4^{\text {th }}$ Advance estimates of area, production and yield of green gram. Agriculture statistics, Department of Agriculture, Govt. of Rajasthan.

Dayanand, Verma, R.K. and Mahta, S.M. 2012. Boosting the mustard production through front line demonstrations. Indian Research Journal of Extension Education. (12):121-123.

Katare, S., Pandey, S.K., and Mustafa, M. 2011. Yield gap analysis of Rapeseedmustard through front line demonstrations. Agriculture Update. 6(2): 5-7.

Meena, B.S., Meena, D.S., Meena, K.C. and Meena, C.B. 2018. Enhanced mustard productivity and profitability through front line demonstration in SouthEastern Rajasthan India. Int. J. Curr.
Microbial App. Sci. 7(7):800-805.

Meena, M.L. and Singh, Dheeraj. 2017. Technological and extension yield gaps in green gram in Pali district of Rajasthan, India. Legume Research. 40(1):187-190.

Mitra, B. and Samajdar, T. 2010. Yield gap analysis of rapeseed-mustard through Front Line Demonstration. Agric. Exten. Review. (April-June):16-17.

Patel, M.M., Jhajhariya, A.K., Khadda, B.S. and Patil, L.M. 2013. Front Line Demonstration: An Effective Communication Approach for Dissemination of Sustainable Cotton Production Technology. Ind. J. Extn. Educn. \& R.D. 21: 60-62, 2013.

Raj, A.D., Yadav, V. and Rathod, J. H. 2013. Impact of Front Line Demonstrations (FLD) on the Yield of Pulses. International Journal of Scientific and Research Publications. 3(9):1-4.

Ram, Baldev, Poonia, S.S., Dhaka, B.L, Poonia, M.K., Meena B.S. and Bairwa, R.K. 2013. Acceleration of Urdbean productivity and profitability under FLDs at humid-eastern plain of Rajasthan. Annals of Agri-Bio research. 6(2): 5-7.

Samui, S.K., Maitra, S., Roy, D.K., Mandal, A.K. and Saha, D. 2000. Evaluation of front line demonstration on groundnut. J. Indian Soc. Coastal Agric. Res., 18(2):180-183.

Singh, G., Sharma, K., Dhaliwal, N.S. and Singh, J. 2012. Boosting Moong productivity through frontline demonstrations. Raj. J. Extn. Edu. 20: 32-34.

Singh, J., Dhillon, B.S. Astha and Singh, P. 2012. Front line demonstration - An effective tool for increasing the productivity of summer Moong in Amritsar district of Punjab. An Asian Journal of Soil Science.7(2):315-318. 


\section{How to cite this article:}

Rupesh Kumar Meena, Bhupender Singh, Kuladip Prakash Shinde and Ravi Kumar Meena. 2020. Cluster Front Line Demonstrations of Green Gram under National Food Security Mission in Sriganganagar District: An Evaluation of Production and Productivity of Green Gram. Int.J.Curr.Microbiol.App.Sci. 9(06): 984-990.

doi: https://doi.org/10.20546/ijcmas.2020.906.123 